\title{
The Financial Determinants of Private Sector Investment: The Case of Ethiopia
}

\author{
Brhane Teklay ${ }^{1,2}$ \\ ${ }^{1}$ National Bank of Ethiopia, Applied Economic Modelling and Forecasting (MA), Addis Ababa University, Addis Ababa, Ethiopia \\ ${ }^{2}$ National Bank of Ethiopia, Statistics Mekelle University (BSc), Addis Ababa, Ethiopia
}

\section{Email address:}

brienbe@gmail.com

\section{To cite this article:}

Brhane Teklay. The Financial Determinants of Private Sector Investment: The Case of Ethiopia. International Journal of Science, Technology and Society. Vol. 5, No. 3, 2017, pp. 46-54. doi: 10.11648/j.ijsts.20170503.14

Received: October 12, 2016; Accepted: April 1, 2017; Published: May 27, 2017

\begin{abstract}
This study mainly emphasized on the financial determinants of private sector investment in Ethiopia using annual time series data from 1975-2015. Using Johansen co integration test they have a significant relationship among variables and OLS regression analysis was undertake to estimate long run model and ECM has been used to find out the short run dynamics. In both long run and short run model the financial determinants variable like broad money supply, bank credit and availability of foreign exchange were positive relation with the private investment. The other macro variable taken was the capital expenditure, which is negatively affect in the long run and positively affect private investment in the short run. The researchers conclude based on past literature result's capital expenditure is positively association with private investment. The short run dynamics of estimated coefficient ECM which suggests a relatively quick speed of adjustment back to the long-run equilibrium. The findings of the study provide evidence that private investment in Ethiopia, like in other developing countries is affected by important financial and macroeconomic variables. The empirical evidence however has certain important policy implications, and in view of that recommendations have also been provided, in an attempt to help increase and stimulate private investment in Ethiopia.
\end{abstract}

Keywords: Ethiopia, Private Investment, Financially Determinants, Johannes Co-integration

\section{Introduction}

\subsection{Background of the Study}

Private sector development involve the improvement of the investment climate which is crucial for sustaining and expanding businesses, stimulating economic growth, and has been the backbone of most developed and developing economies. The private sector is recognized as a critical stakeholder and partner in economic development, by helping people escape poverty through the provision of jobs and income, as well as the availability of necessary goods and services needed to enhance people's standard of living (International Finance Corporation, 2011). Private investment is thus a powerful catalyst for economic growth and innovation as well as a poverty reduction facilitator and hence its role is important both in terms of its contribution to GDP and its ability to allocate and employ resources efficiently.
For developing countries like Ethiopia the basic question in their economy is increase the production and hence improve the standard of living of their people so that there will be dramatic change in their economic, political and social conditions. Investment promotion is one key instrument and primary engine of economic growth (Mustefa, 2014). As a result due attention has been given to development of private sector in developing countries to help improve economic growth (Ouattara, 2004). Reliable and continuous increase in domestic private investment also helps in reduction of poverty.

Ethiopia is an investment friendly country with a stable macro-economic environment. Its monetary policy have played a significant role in creating an enabling climate to addressing the need of the public, assisting the economic activity and attractive to investors. Ethiopia has been taking suitable measures in improving the investment policy of the country with aim of promoting sustainable economic development. 
This study is aimed at filling this research and knowledge gap in Ethiopia by assessing the effects of some selected financial development indicators on private investment in Ethiopia. Whilst controlling for the effect of non-financial factors, the findings would provide empirical information on how effectively the financial sector deregulation and its accompanying reforms have influenced private investment in Ethiopia. In this study public investment also includes as one of the explanatory variable to see whether crowding in or crowding out private investment other than financial factor.

Using annual time series data from 1975 to 2015, the model will be estimated using the Error Correction Model (ECM) where the short run and long run effects were established. The study use the variable private investment as dependent variable and variables like credit to private sector, broad money supply, interest rate, inflation rate, availability of foreign exchange GDP growth and capital expenditure (as proxy of public investment) as explanatory variable. Many literatures also use these variables to explain the financial determinants of private investment.

\subsection{Statement of Problem}

In the region of East Africa almost $70 \%$ of labor force is engaged in agriculture and low investment rate keeps large population to live in under poverty. Needs required to transform agrarian based to industrialized led economy and coordination of every sector of the economy, creating forward and backward linkages of sectors of the economy are desirable. In the given dimension, the private sector plays a fundamental role to equip economy with employment, technology transfer, innovating, inventing and able to use the resources efficiently and less prone to corruption.

The Ethiopian economy is manifested by different economic reforms and structural changes in respective regimes. For instance, following the revolution a number of reforms have been undertaken. Accordingly, the government brought large scale agricultural farms, industries, financial institutions etc under its direct control. In such a way the central bank controls monetary policy variables on behalf of the government. Moreover, the proclamation issued in 1975 was aimed at to insist the people to invest on enterprise larger than cottage industries. But, it is not hidden for everyone that the contribution of the private investment was insignificant.

Since the start of economic reform of 1991, Ethiopia has embarked on policies that aim to rebalance the role of public and private sector in the economy and thus emphasize private sector development. This is a major departure from the socialist policies of Dergue period that relied heavily on public sector institutions (DemilieBashaHailu, FikruDebele, 2015).

In Ethiopia, both fiscal and monetary policies seem to be ineffective during the respective regimes. For example, during the command economy, as shown in the study of Mongbay (2010), in the 1980s the government adopted a conservative fiscal management as well as price control and officially over valuing of birr to curb inflation but inflation was averaging $7.1 \%$ annually which is turned up during 1990 due to war expenditure. Moreover, currently monetary policy seems aimed at increasing the amount of cash available at banks lending.

This paper is concerned with conducting an empirical analysis of the effects of financial sector on private investment in Ethiopia. The paper is important for improve upon previous empirical research by using a broad and more comprehensive data set on financial sector reforms. This is done by developing an index of the reforms, which takes into account the initial conditions at start of the reforms, and characterizes the sequencing of various reform measures. This index is then included in private investment equations to determine the effect of financial reforms on private investment and because we make use of this index of financial reforms, the results will provide a more robust analysis of the impact of financial reforms on private investment than earlier studies have done.

\subsection{General Objectives of the Study}

The main objective of this study has focused on identifying the financial determinant of private sector investment in Ethiopia.

\subsection{Specific Object of the Study}

a. To examine the trends of private sector investment across different time periods in Ethiopia.

b. To point out which factor are significantly determines private sector investment activities in Ethiopia.

c. To figure out the response of private sector investment when the expected explanatory variables changes.

d. Investigate the direction and magnitude of the impact of financial determinants on private sector investment both in the short run and long run.

e. To know did public investment crowd in or crowd out private investment in Ethiopia.

\section{Literature Review}

\subsection{Theoretical Literature Review}

There are different models that are used to frame and shape the theoretical frameworks of the study. Many scholars used different types of models and fit the argument with the realization of these theoretical baselines about investment. These models are simple accelerator model, Tobin Q theory and flexible accelerator/ neoclassical model and attempt is made to address explicit detail below.

The existence of an independent investment function in an economy was stated by Keynes (1936) with the basic features of saving and investment are equivalent in the ex-post situation while decisions are taken by different bodies and equality of ex-ant saving and investment activities lacks real justification. Next to this, the accelerator theory of investment states that investment is a linear function of output change in the economy. This theory has not given emphasis to the cost of capital goods, expectation and profit in its model. Simple accelerator model. 
The basic idea of accelerator theory states that investment responds to the changing demand conditions, thus net investment is given by the change in the desired output: As demand (income) increase, investment made by firms also increases. Thus, when output is expected to increase, capital stock increases consistent with the given level of output. Investment is a function of the difference between the existing and desired capital stock and replacement capital needed to replace worn out of the existing capital stock.

\subsection{Empirical Literature Review}

Previous empirical works have also sought to explain the relationship between selected macroeconomic and financial variables and their effect on private investment. Ndikumana (2000) investigated the effects of financial development on domestic investment in a sample of 30 sub-Saharan African countries based on panel data econometric techniques. The study was based on a dynamic serial-correlation investment model which included various indicators of financial development, and nonfinancial factors of investment.

Moshi and Kilindo (1999) conducted an empirical study on the role of government policy on private investment in Tanzania using data over the period 1970-1992. The results of regression estimates showed a positive and significant relationship between private investment and GDP growth, private sector credit, and public investment. The authors used another specification where public investment was split into central government investment and parastatal sector investment. The estimated results showed that all the variables were positive and statistically significant with the exception of central government investment which was significantly negative, thus providing evidence of crowdingout.

Asante's (2000) study sought to examine the determinants of private investment in Ghana over the period 1970-1992. The results showed that the variables that had a significant positive relationship with investment are: lagged investment, public investment, private sector credit, real interest rate, and real exchange rate. Trade, political instability, macroeconomic instability, and the growth rate of real GDP have had a negative relationship with private investment.

Furthermore, in the area of input-output relationship of public and private sector investments also mentioned as complementarities when the output of the public sectors used as input for the private sector investments. On the contrary, the output product of the two investment sectors may compete with each other and 'crowds-out' the private one (Khan and Kumar 1997). In another channel, when public investment run under budget constraints and financed by imposing high tax rates leaves undesirable impact on private investments since it raises the cost of inputs and causes to decline expected output growth. Likewise, when it is financed by market borrowing, it imposes restrictions on resources allocated to the private sectors and affect private investments negatively.

Seruvatu and Jayaraman (2001) wrote that, the policy related variables have to take into account government consumption spending which affects availability of savings for the private sector. The "crowding out" effects of government expenditure are reflected in credit availability for the private sector. Zerfu's study on the determinants of private investment in Ethiopia suggests that, public investment on infrastructure projects has a positive externality on private investment. This implies the complementarity nature of private investment and the availability of infrastructure, at least in the long run. Thus, the government can stimulate private investment by investing on infrastructure projects.

\section{Research Design and Methodology}

\subsection{Data Sources and Coverage}

The study uses secondary time annual series data from 1975 to 2015, and its main source is from the National Bank of Ethiopia and Ministry of Financial and Economic Corporation. The variable Private investment would be used as dependent variable, and credit to private sector, broad money supply, inflation rate, availability of foreign exchange, Capital expenditure (as proxy of public investment) and GDP growth as independent variables. EVIEW'S software is for estimation and evaluation of the model.

\subsection{Model Specification}

To determine the effect financial determinants of private sector investment in Ethiopia, the multiple regression analysis and co-integration methods are used to estimate the parameters of the model. The Regression Coefficient is estimated using Ordinal Least Squares. The private investment function has been specified using the following Econometric Model. In the next chapter the researcher well carryout all the necessary tests of like stationary test, cointegration test, long run and short run model specification and Model Fitness and Diagnostic Checking. The main variables under consideration are taken from theoretical setups and empirical evidences in different countries. The dependent variable of study is specified as:

$$
P I_{t}=f\left(M 2_{t}, B C_{t}, A F E, C P I, C E, G D P\right)
$$

Where $\mathrm{t}=1,2,3 \ldots .41$ (time period ranging from 1975 to 2015)

$\mathrm{PI}=$ private investment in time $\mathrm{t}$.

M2 = Broad Money Supply

$\mathrm{BC}=$ Bank credit availability

$\mathrm{CE}=$ Capital expenditure

GDPG $=$ Gross Domestic Product Growth

$\mathrm{AFE}=$ availability of foreign exchange

$\mathrm{CPI}=$ consumer price index 
Equation (1) can be rewritten for estimation purpose as follows:

$$
l P I_{t}=\partial_{0}+\partial_{1} l M 2_{t}+\partial_{2} l B C_{t}+\partial_{3} l A F E_{t}+\partial_{4} l C P I+\partial_{5} G D P G_{t}+\partial_{6} l C E_{t}+\varepsilon_{t}
$$

Where $\partial_{0}$ is the intercept and $\partial_{1}, \partial_{2}, \partial_{3}, \partial_{4}, \partial_{5}, \partial_{6}$, are the coefficients of $\mathrm{M} 2, \mathrm{BC}, \mathrm{AFE}, \mathrm{CPI}, \mathrm{GDPG}$ and $\mathrm{CE}$ respectively. $\mathcal{E}_{t}$ is error term.

All variables are in natural logarithm except GDPG. Log transformation can reduce the problem of heteroscedasticity because it compresses the scale in which the variables are measured, thereby reducing a tenfold difference between two values to a twofold difference (Gujarati, 1995). It is important to note that the model is a multiplicative one where all parameter coefficients represent constant elasticities.

\subsection{Variables Selection and Theoretical Assumption}

\subsubsection{Dependent Variable}

Private investment: - is used as the dependent variable. In many cases, this refers to a private business that has a limited number of share holders the utilization in national territory of capital, capital equipment and other assets, in specific economic projects, or the utilization of funds assigned for the setting up of new companies, association or other forms of corporate representation of private domestic or foreign companies, as well as the acquisition of the whole or part of existing companies incorporated under the country law, with a view to the implementation or continuity of a specific economic activity in accordance with their corporate purposes. Because of unavailability of time series data of private investment the researcher used the proxy for private investment as the following formula.

$T I=C E+P I$ And $G C F=C E+P I$ then $P I=G C F-C E$

Where $\mathrm{TI}=$ total investment, and $\mathrm{GCF}=$ gross capital formation $\mathrm{CE}=$ capital expenditure.

\subsubsection{Independent Variable}

Broad Money: The ratio of broad money supply to GDP is conventionally used as a measure of financial sector deepening (Nnanna, 2006). It gauges the increased provision of financial services to the financial sector based on how liquid money is. An increase in the money supply will ease the financing conditions of households and firms, which is reflected in lower lending rates and ultimately enhanced availability of credit to private investors which spurs investment. Thus a priori, the coefficient of broad money supply in private investment equation is expected to have a positively sign $\left(\partial_{1}>0\right)$.

Bank credit to private sectors: An increase in real interest rates encourages deposits and, hence, increases the availability of funds to the private sector to finance investment projects while discourage low-yield projects. In contrast, the theory emphasizing the role of asymmetric information in financial markets predicts that an increase in interest rates causes credit rationing because the lenders expected profitability is not monotonically increasing in interest rates. At higher rates, lenders may experience a decrease in profits due to adverse selection, moral hazard, and monitoring costs. Therefore, lenders are not willing to lend at a rate higher than that which maximizes their expected profits, even though there are agents willing to borrow at that higher rate. Increasing credit by the banking sector to the private sector is likely to boost private sector investment. Thus the effect of credit to the private sector is expected to be positive $\left(\partial_{2}>0\right)$.

Availability Foreign Exchange (FEA):- is one of the crucial determinants of financial sector variablees in determining the economy's capacity to import machineries and equipment for the private sector investment. As a result the researcher expects positive affect on the dependant variable. $\left(\partial_{3}>0\right)$.

Inflation Rate: High rates of inflation send out a signal that the government is unable to manage the economy properly and is a sign of instability. There is also the possibility that the actions of the government in attempting to control inflation through contractionary policies might depress demand and this would result in a fall in investment. High and unpredictable inflation rates can be portrayed by investors as a sign that the government is losing control of the economy and thus discourage investor confidence. In this way, the researcher expects a negative link between investment and macro economic uncertainty is established. $\left(\partial_{4}<0\right)$

Gross Domestic Price: Real GDP is used to capture the aggregate demand conditions in the economy and it is expected to exert a positive effect on private investment. In addition to the determinants mentioned above, private investment spending depends on output, economic reform policy, and on its own lagged values. Since the early study of Clark (1917), the change in output is considered as a determinant of investment spending. This effect is the well known "accelerator effect". Output also plays an important role in the neoclassical approach of investment introduced by Jorgenson (1963), although the central feature of this theory is to evaluate the effects of relative prices on the demand for capital. Output affects investment decisions due to its effect on firms' profitability and also by means of the output-savingaggregate investment channel. Consequently, the study expects the coefficient of real GDP to be positive $(24>0)$.

Public Investment: is included in our model and it highlights the importance of the government providing a conducive environment for investment to take place. The relationship between private and public investment is theoretically ambiguous. An increase in public investment can have either a positive or negative effect on private investment. On the one hand, public investment can raise private investment in a situation where resources are not fully employed. In such a case, income would increase following an increase in public investment and this increased income would send positive signals to private investors that they can increase their profit 
margins by investing more. On the other hand, however, public investment will be a substitute for private investment if it is financed through inflation or debt issues. Public investment can also be detrimental to private investment if the goods produced by the public sector compete directly with private sector produced goods. Thus, this crowding out of private investment by public investment makes them substitutes. The exact relationship between private and public investment can only be ascertained empirically.

\subsection{Unit Root Test}

The reason for starting with the Augmented Dickey-Fuller test is that there is no uniformly better test. This should not be understood as a motive for not performing other types of unit root tests. Comparing different results from different test methods is a good way of testing the sensitivity of your conclusions

If the variables in the regression model are not stationary, then it can be proved that the standard assumptions for asymptotic analysis will not be valid. In other words, the usual "t-ratios" will not follow at distribution, so we cannot validly undertake hypothesis tests about the regression parameters. Due to this reason the researcher well undertake the stationary test using ADF.

\subsection{Testing for Co-integration}

In the case of co- integration recognizing the fact that most macroeconomic data are non stationary. Co-integration is a popular econometric technique which is used to find long run relationship between variables. A regression involving nonstationary variables (variables with unit roots) is meaningful if the variables are co-integrated, i.e. have long run relationship. According to time series econometrics, if the residuals from a regression involving non-stationary variables are stationary then the variables are said to be cointegrated. This is because even if the variables are individually non stationary their linear combinations are stationary which is despite by the stationarity of the residuals. The analysis is preceding using Johansen co-integration test

\subsection{Long Run Model Specification}

Long Run OLS estimation result shows in model private investment determined by how many percent of R-squared by the independent variables as well as by what percentage of Adjusted R- Squared (coefficient of determination) measures the proportion or percentage of the total variation in dependent variable explained by the regression model.

The specification of the model can be written as follow:-

$$
l P I_{t}=\partial_{0}+\partial_{1} l M 2_{t}+\partial_{2} l B C_{t}+\partial_{3} l A F E_{t}+\partial_{4} l C P I+\partial_{5} G D P g+\partial_{6} l C E_{t}+\varepsilon_{t}
$$

\subsection{Short Run Model Specification}

Economic theory is mostly interested in equilibrium conditions and has little to say about the nature of economic configurations in disequilibrium. While economic theory proposes that certain macro variables have equilibrium relationships with each other, the data does not confirm that these hold at all times. To overcome this difficulty, economists make a distinction between the short-run and the long-run.

ECM has been used to find out the short run dynamics.
The term 'error correction models' applies to any model that directly estimates the rate at which changes in dependent variable return to equilibrium after a change in independent variable. The ECM model has a nice behavioral justification in that it implies that the behavior of dependent variable is tied to independent variable in the long run and that short run changes in dependent variable respond to deviations from that long run equilibrium.. Short Run model specification is given as:

$$
\begin{aligned}
& D l P I_{t}=\partial_{0}+\partial_{1} D l M_{2 t}+\partial_{2} D l B C_{t}+\partial_{3} D L A F E_{t}+\partial_{4} D L C P I_{t}+\partial_{5} D G D P G_{t}+ \\
& \partial_{6} D L C E_{t}+\gamma E C M(-1)
\end{aligned}
$$

\section{Result and Discussion}

\subsection{Unit Root Test Result}

Table 1. Result of unit root test.

\begin{tabular}{llll}
\hline & ADF Test at level & & ADF Test at 1st difference \\
\cline { 2 - 4 } & Constant & Constant +Trend & Constant \\
\cline { 2 - 4 } & Actual value (t-cal) & Actual value (t-cal) & Actual value (t-cal) \\
\hline LPI & 0.64 & $-3.87^{* *}$ & $-5.03^{*}$ \\
LCE & 1.64 & -0.20 & $-5.56^{*}$ \\
LBC & -1.79 & -3.33 & $-7.22^{*}$ \\
LM $_{2}$ & -1.99 & 0.96 & $-3.35^{* *}$ \\
LAFE & 0.05 & -2.02 & $-6.81^{*}$ \\
LCPI & 0.23 & -1.09 & $-5.71^{*}$ \\
\hline
\end{tabular}

Note

$\mathrm{t}$ critical without trend at $1 \%=-3.61$ and $5 \%=-2.93$ with trend and intercept at $1 \%=-4.21$ and at $5 \%=-3.52$

* represents significant level at $1 \%$. And ** represent significant level at $5 \%$. 
The above table indicates the unit root test result of the variable using Schwarz info criterion (SIC) type. For this test Schwarz Info Criterion test was used to select the maximum lag length. All variables are stationary at first difference with trend and without trend at $1 \%$ level of significance except LPI which is stationary at level at $5 \%$ level of significance.

\subsection{Testing for Co-integration}

In order to check for the existence of long run relationship, co integration, in the model a Johansen co integration test was used to check whether have a long run relation among the variable's or not. There may be more than one co-integrating relationship among co-integrated variables. Johansen test provides estimates of all such co integrating equations and provides a test statistic for the number of co integrating equations.

Table 2. Co-integration test (Trace).

\begin{tabular}{lllll}
\hline \multicolumn{2}{l}{ Unrestricted Co integration Rank Test (Trace) } & & & $\mathbf{0 . 0 5}$ \\
\hline Hypothesized & & Trace & Critical Value & Prob.** \\
\hline No. of CE(s) & Eigen value & Statistic & 95.75366 & 0.0000 \\
\hline None & 0.745110 & 134.5428 & 69.81889 & 0.0034 \\
At most 1 & 0.680902 & 82.59970 & 47.85613 & 0.2526 \\
At most 2 & 0.374130 & 39.19389 & 29.79707 & 0.3340 \\
At most 3 & 0.249930 & 21.38661 & 15.49471 & 0.2471 \\
At most 4 & 0.169665 & 10.45822 & 3.841466 & 0.0655 \\
At most 5 & 0.085420 & 3.393038 & & \\
\hline
\end{tabular}

Trace test indicates 2 co integrating eqn(s) at the 0.05 level

* denotes rejection of the hypothesis at the 0.05 level

**MacKinnon-Haug-Michelis (1999) p-values

The result from the above table 2 indicated in trace test have 2 co integration equation at $1 \%$ level of significance and in Max-eigen value test have also 2 co integration equation at the $1 \%$ level of significance. There for variables in the long run model has a meaning full economic relationship.

\subsection{Long Run Model}

The long run OLS EVIEWS estimation result of output can be rewrite as follow:

$$
l P I_{t}=\partial_{0}+0.35 * l M 2_{t}+0.09 * l B C_{t}+0.45 * l A F E_{t}-0.41 * l C P I+0.01 * G D P g-0.16 * l C E
$$

Table 3. LR OLS Estimation Result.

\begin{tabular}{|c|c|c|c|c|}
\hline \multicolumn{5}{|c|}{ Dependent Variable: LPI } \\
\hline \multicolumn{5}{|c|}{ Method: Least Squares } \\
\hline Variable & Coefficient & Std. Error & t-Statistic & Prob. \\
\hline LM2 & 0.351482 & 0.165002 & 2.130161 & 0.0407 \\
\hline LBC & 0.095530 & 0.056362 & 1.694944 & 0.0995 \\
\hline LAFE & 0.450790 & 0.105873 & 4.257837 & 0.0002 \\
\hline LCPI & -0.411115 & 0.180578 & -2.276666 & 0.0294 \\
\hline GDPG & -0.011729 & 0.005337 & -2.197662 & 0.0351 \\
\hline LCE & -0.164161 & 0.206821 & -0.793731 & 0.4330 \\
\hline $\mathrm{C}$ & 4.183863 & 0.582297 & 7.185097 & 0.0000 \\
\hline R-squared & 0.919724 & \multicolumn{2}{|c|}{ Mean dependent var } & 10.24848 \\
\hline Adjusted R-squared & 0.905128 & \multicolumn{2}{|c|}{ S.D. dependent var } & 0.523129 \\
\hline S.E. of regression & 0.161130 & \multicolumn{2}{|c|}{ Akaike info criterion } & -0.655579 \\
\hline Sum squared resid & 0.856778 & \multicolumn{2}{|c|}{ Schwarz criterion } & -0.360025 \\
\hline Log likelihood & 20.11157 & \multicolumn{2}{|c|}{ Hannan-Quinn criter. } & -0.548716 \\
\hline F-statistic & 63.01351 & \multicolumn{2}{|c|}{ Durbin-Watson stat } & 1.547545 \\
\hline Prob (F-statistic) & 0.000000 & & & \\
\hline
\end{tabular}

The above table 3 OLS long run regression result indicates the coefficient of parameters variables are describes as follow. As expected in the above $\mathrm{M}_{2}$ in both long run and short run is positive and significantly in the long run only affect private investment. As stated in the above theoretical expectation as $\mathrm{M}_{2}$ increases private investment also increase by $35 \%$ in the long run. This is interpreting as $\mathrm{M}_{2}$ increase by one unit private investment also increase by $35 \%$.
The other variable that describes the main variable is $\mathrm{BC}$. In the long run model as expected there is positive and significant at $10 \%$ level of significance relation with private investment but in the short run even is it positively relation it is not a significant value. Interpret as bank credit increase by one unite private investment also increase by $9 \%(0.09)$, so bank credit is improves private sectored investment.

As expected in the theoretically literature availability of 
foreign exchange also has positive and significant relation with private investment in long run and short run model. And interpreted around $45 \%$ is affecting private investment in the long run.

The coefficient of CPI is negative and significant value as expected in the theoretical assumption in both models. The coefficient in the long run -0.16 measures change in the private investment when other things remain constant, and the negative value interprets as CPI change by one unit price private investment decrease by $16 \%$.

$\mathrm{CE}$ also take as independent variable measure for the private investment and in both long run and short run model output is it not significant with coefficient negatively and positive respectively. As the researcher conclude based on past literature result capital expenditure is positively association with private investment, therefore privates investment is affected by $41 \%$ in the short run and the positive value shows capital expenditure is crowed in private investment, This result also concludes different scholars. Accordingly, Serven (1998), He argued that an increase in public infrastructure on the road, telecommunication and electric city raises the long run private capital stock by reducing the cost of capital to the private sector.

GDPG in the long run and in the short run is positive significant relation with the main variable. As stated in the above theoretical expectation as GDPG increases private investment also increase by $1 \%$ in the long run. To estimate the long run as well as the short run model the growth of GDP was used and that why is the number very small effecting private investment.

\subsection{Short Run Dynamics}

ECM has been used to find out the short run dynamics. The results of short run dynamics of the variables are reported in table- 4 .

Table 4. Short run model out put.

\begin{tabular}{|c|c|c|c|c|}
\hline \multicolumn{5}{|c|}{ Dependent Variable: DLPI } \\
\hline \multicolumn{5}{|c|}{ Method: Least Squares } \\
\hline Variable & Coefficient & Std. Error & t-Statistic & Prob. \\
\hline DLM2 & 0.274099 & 0.501513 & 0.546544 & 0.5886 \\
\hline DLBC (1) & 0.016918 & 0.068538 & 0.246840 & 0.8067 \\
\hline DLAFE & 0.333589 & 0.138504 & 2.408515 & 0.0222 \\
\hline DLCPI & -0.557878 & 0.239700 & -2.327396 & 0.0266 \\
\hline DGDPG & 0.015740 & 0.003674 & -4.284634 & 0.0002 \\
\hline DLCE (1) & 0.419931 & 0.211833 & 1.982367 & 0.0564 \\
\hline $\operatorname{ECM}(-1)$ & -0.808264 & 0.176208 & -4.586979 & 0.0001 \\
\hline $\mathrm{C}$ & -0.032791 & 0.064055 & -0.511915 & 0.6123 \\
\hline R-squared & 0.720709 & Mean dependent var & & 0.035982 \\
\hline Adjusted R-squared & 0.657644 & S.D. dependent var & & 0.263194 \\
\hline S.E. of regression & 0.153998 & Akaike info criterion & & -0.723071 \\
\hline Sum squared resid & 0.735178 & Schwarz criterion & & -0.381828 \\
\hline Log likelihood & 22.09989 & Hannan-Quinn criter. & & -0.600636 \\
\hline F-statistic & 11.42793 & Durbin-Watson stat & & 2.118594 \\
\hline Prob (F-statistic) & 0.000000 & & & \\
\hline
\end{tabular}

The above EVIEWS result of short run output can be rewrite as follow:

$$
\begin{aligned}
& \mathrm{DLPI}=0.27 * \mathrm{M}_{2}+0.01 * \mathrm{DLBC}+0.33 * \mathrm{DLAFE}-0.55 * \mathrm{DLCPI}+ \\
& 0.01 * \mathrm{DGDP}+0.41 * \mathrm{DLCE}(1)-0.80 * \mathrm{ECM}(-1)
\end{aligned}
$$

From the above results, the broad money supply with an elasticity coefficient of 0.27 was not significant. The sign was the same to what was obtained in the long run case. The result implies that in the short-run, a percentage increase in the ratio of broad money supply will increase a 27 percent in private investment. Bank credit in the short run also insignificant however its sign is as expected and the same to the long run model result.

In the short run model the variable AFE and GDPG are significantly affect private investment and the sign also positively as expected in the theoretically literature. The result also the same to what was obtained in the long run.

Consistent with the long-run finding, the elasticity coefficient of inflation was found to be negative and significant at the 1 percent level in the short-run. Inflation, which is a sign of macroeconomic instability, has the potential of driving down private investment by 55 percent.
Thus in both the short-run and long-run, inflation has the potential of deterring private sector investment.

$\mathrm{CE}$ also take as independent variable measure for the private investment and in both long run and short run model output is it not significant with coefficient negatively and positive respectively. As the researcher conclude based on past literature result capital expenditure is positively association with private investment, therefore privates investment is affected by $41 \%$ in the short run and the positive value shows capital expenditure is crowed in private investment, This result also concludes different scholars. Accordingly, Serven (1998), He argued that an increase in public infrastructure on the road, telecommunication and electric city raises the long run private capital stock by reducing the cost of capital to the private sector.

The ECM represents the speed of adjustment to restore equilibrium in the dynamic model following a disturbance. 
The estimated coefficient of the ECM which equals (-0.80) suggests a relatively quick speed of adjustment back to the long-run equilibrium. The coefficient is highly significant at the 1 percent significance level and appropriately signed. According to Verma (2007), a highly significant error correction term is further proof of the existence of a stable long -run relationship. The result suggests that about 80 percent of the deviation between the actual and the long-run equilibrium value of private investment is corrected each year. That is approximately more than 80 percent of the disequilibria from the previous year's shock converge back to the long-run equilibrium in the current year.

\subsection{Model Fitness and Diagnostic Checking}

R-Squared (coefficient of determination) measures the proportion of the variation in the dependent variable accounted for by the explanatory variables and interpreted as the dependant variable private investment was explained or predicate by $72 \%$ of the independent variable. Adjusted RSquared measures the percentage of variation explained by only those independent variables that in reality affect the dependent variable. The value 0.65 depicts that 65 percent explained the dependant variable by the independent variables. Which is the most commonly used measure of the goodness of fit of a regression. (Gujarati)

The value of Durbin Watson Statistics is the most celebrated test for detecting the existence of serial correlation. To use the DW test, we have to assume these assumption (i) the regression model contains an intercept, (ii) the error process is AR1 (the test says nothing about higher order autocorrelation), (iii) the error term is normally distributed, (iv) there is no lagged dependent variable, and (v) there are no missing observations in the data.

The second test for serial correlation is the BreuschGodfrey (BG) or Lagrange Multiplier (LM) Test. The BG test is useful in that it allows for (i) lagged dependent variables, (ii) higher order autoregressive processes as well as single or higher order moving average processes. The basic idea is to regress the residuals from the OLS regression on all of the independent variables and on the lagged values of the residuals.

The hypothesis test for the serial correlation is as follow:

$\mathrm{H}_{0}=$ There is no problem of serial correlation and the alternative hypothesis

$\mathrm{H}_{1}=$ At least one has a problem of serial correlation.

The researcher applied all the necessary diagnostic tests on the model like normality, serial correlation, multicollinarity, heteroscedasticity and model specification. The results, reported in appendicesadvocate that the model is passed the assumption of normality, no problem of serial correlation and there is no problem of heteroscedastiy. And the model also checking the specification using Ramsey's RESET test. The $\mathrm{ARCH}$ test also negates or cancels out the presence of autoregressive conditional heteroscedasticity.

\section{Conclusion and Recommendation}

This paper investigated the financial determinants of private investment in Ethiopia by specifying a private investment model. The objective of the paper was to determine whether the financial determinants have contributed to improve private investment in Ethiopia. Using annual time series data from 1975 to 2015, an Error Correction Model (ECM) was estimated. The study concluded that the result of the analysis confirmed the basic findings of some earlier studies that the actual impact of government expenditure on private sector investment varies depending on the type of government expenditure under consideration.

Stationarity of variables of time series was checked by using Augmented Dickey-Fuller (ADF) unit root test. The results from the model show the existence of long run relationship among the variables. In order to check for the existence of long run relationship Johannes's co integration was applied.

The coefficient of ECM represents the speed of adjustment to restore equilibrium in the dynamic model following a disturbance. The estimated coefficient of the ECM which equals $(-0.80)$ suggests a relatively quick speed of adjustment back to the long-run equilibrium. The coefficient is highly significant at the 1 percent significance level and appropriately signed.

The findings of the study provide evidence that private investment in Ethiopia, like in other developing countries is affected by important financial and macroeconomic variables. The empirical evidence however has certain important policy implications, and in view of that recommendations have also been provided, in an attempt to help increase and stimulate private investment in Ethiopia.

In both long run and short run model the financial determinants variable like broad money supply, bank credit and availability of foreign exchange were positive relation with the private investment.

The other macro variable taken as independent variable was the capital expenditure, which is negatively affect private investment in the long run and positively affect private investment in the short run. The researchers conclude based on past literature result's capital expenditure is positively association with private investment. This result also conclude different scholars Serven (1998), He argued that an increase in public infrastructure on the road, telecommunication and electric city raises the long run private capital stock by reducing the cost of capital to the private sector.

Based on empirical results of the study the researcher recommended to those policy makers especially on monetary policy to provided that broad money supply, bank credit and availability of foreign exchange have positive effect on the private investment sector, as a result the monetary policy or these financially institution be muscularly apprehension on these private sector investors by boosting credit and available of foreign exchange for those investor require imported raw materials. 
The other very crucial point is Ethiopia is the fastest economic growth with huge population size however, still we don't have capital market for easy financing those who have an idea and they don't afford on the private sector investment therefore introducing capital market to the economy solve such a problem. Finally encouraging the expansion in private sector investment towards the government capital investment rising in public expenditures on the provision of infrastructure for rural areas will also be helpful for finest private investment.

\section{References}

[1] Aizenman, J., and N. P. Marion (1993), "Macroeconomic Uncertainty and Private Investment," Economics Letters, 41, 207-210.

[2] Ang, James B. "Determinants of private investment in Malaysia", Western Economic Association International. ISSN: $1074-3529$.

[3] Asante, Y. (2000), "Determinants of Private Investment Behaviour," AERC Research Paper, 100, Nairobi: African Economic Research Consortium.

[4] Blejer, M. I. and M. S. Khan (1984) 'Government Policy and Private Investment in Developing Countries', Staff PapersInternational Monetary Fund: 31 (2), 379-403.

[5] Dailami, M., and M. Walton (1992), "Private Investment, Government Policy and Foreign Capital: A Study of the Zimbabwean Experience," in A. Chhibber, M. Dailami, and N. Shafik (eds.), Reviving Private Investment in Developing Countries: Empirical Studies and Policy Lessons, North Holland.

[6] Esubalew, T. A, (2014), “An Investigation of Macroeconomic Determinants of Domestic Private Investment Evidence from East Africa" International Institution of Social Science.

[7] Fairbairn, T. I. J. (1992). Private Sector Development in the South Pacific: Options for Donor Assistance, Pacific Studies Monograph No. 3, The Centre for South Pacific Studies, University of New South Wales.

[8] Fischer, S. E. Hernandez-Cata and M. S. Khan (1998). Africa: Is this the Turning Point? IMF Paper on Policy Analysis and Assessment 98/6, May.

[9] Fry, M. J. (1989) 'Foreign Debt Instability: An Analysis of National Saving and Domestic Investment Responses to
Foreign Debt Accumulation in 28 Developing Countries', Journal of International Money and Finance 8 (3): 315-344.

[10] Fowowe, B. (2011). Financial Sector Reforms and Private Investment in Sub-Saharan African Countries. Journal of Economic Development, Volume 36, Number 3.

[11] Geda, A. (2006), "The structure and performance of Ethiopia's financial sector in the pre- and post-reform period with a special focus on banking" UNU-WIDER, United Nations University (UNU), No. 2006/112 ISBN 9291908967.

[12] Herandez-Cata, E. (2000). Raising Growth and Investment in Sub-Saharan Africa: What Can be Done? Policy Discussion Paper: PDP/00/4, International Monetary Fund, Washington, D. C.

[13] Lensink, R. (1996), "The Allocative Efficiency of the Formal versus the Informal Financial Sector," Applied Economics Letters, 3 (3), 163-165.

[14] Maame E. E. and George A. and Emmanuel B., (2014) "The Financial Determinants of Private Investment in Ghana (ARDL approach)"Munich Personal RePEc Archive No. 57570 .

[15] Matsheka, T. C. (1998), "Interest Rates, and the SavingInvestment Process in Botswana," African Review of Money Finance and Banking, 1 (2), 5-23.

[16] Osmond C. A. (2015), "Determinants of Private Investment in Nigeria an Econometric Analysis" International Journal of Economics, Commerce and Management Vol. III ISSN 2348 0386.

[17] Oshikoya, T. W. (1992), "Interest Rate Liberalization, Savings, Investment and Growth: The Case of Kenya," Savings and Development, 16 (3), 305-320.

[18] Oshikoya, T. W. (1994), "Macroeconomic Determinants of Domestic Private Investment in Africa: An Empirical Analysis," Economic Development and Cultural Change, 42 (3), 573-596.

[19] Pfeffermann, G. P. and A. Madarassy (1992) 'Trends in Private Investment in Developing Countries': International Finance Corporation: The World bank, Washington D. C.

[20] Seck, D., and Y. H. El Nil (1993), "Financial Liberalization in Africa," World Development, 21 (11), 1867-1881.

[21] Serven L. (1997), "Uncertainty, Instability, and Irreversible Investment: Theory, Evidence, and Lessons for Africa," Policy Research Working Paper, 1722, Washington D. C.: World Bank. 